\title{
PERAN INOVASI PRODUK DALAM MEMEDIASI PENGARUH ORIENTASI PASAR TERHADAP KINERJA PEMASARAN
}

\author{
Komang Satya Devara ${ }^{1}$ \\ Eka Sulistyawati ${ }^{2}$ \\ ${ }^{1,2}$ Fakultas Ekonomi dan Bisnis Universitas Udayana, Bali, Indonesia \\ email: devara098@gmail.com
}

\begin{abstract}
ABSTRAK
Tujuan dari penelitian ini adalah untuk menjelaskan inovasi produk berperan dalam memediasi pengaruh orientasi pasar terhadap kinerja pemasaran. Penelitian ini dilakukan pada UKM industri fashion di Kota Denpasar. Jumlah sampel dalam penelitian ini sebanyak 50 responden. Teknik pengambilan sampel yaitu non-probability sampling dengan menggunakan metode purposive sampling. Pengumpulan data diperoleh dari hasil penyebaran kuesioner UKM industri fashion di Kota Denpasar. Analisis data dalam penelitian ini menggunakan analisis jalur dan uji sobel. Hasil analisis jalur dan uji sobel menunjukan bahwa variabel inovasi produk berperan dalam memediasi pengaruh orientasi pasar terhadap kinerja pemasaran UKM industri fashion di Kota Denpasar. Hasil penelitian ini menunjukan bahwa semakin baik UKM industri fashion di Kota Denpasar melakukan inovasi produk maka pengaruh orientasi pasar terhadap kinerja pemasaran semakin besar. Kata kunci: orientasi pasar, inovasi produk, kinerja pemasaran
\end{abstract}

\begin{abstract}
The purpose of this study is to explain product innovation plays a role in mediating the effect of market orientation on marketing performance. This research was conducted at the fashion industry UKM in Denpasar City. The number of samples in this study were 50 respondents. The sampling technique is non-probability sampling using the purposive sampling method. Data collection was obtained from the results of questionnaires in the fashion industry SMEs in Denpasar City. Data analysis in this study used path analysis and sobel test. The results of path analysis and sobel test show that product innovation variables play a role in mediating the effect of market orientation on the marketing performance of the fashion industry SMEs in Denpasar City. The results of this study indicate that the better the fashion industry SMEs in Denpasar City make product innovations, the greater the influence of market orientation on marketing performance.

Keywords: market orientation, product innovation, marketing performance
\end{abstract}




\section{PENDAHULUAN}

Pada umumnya makanan, tempat tinggal, dan pakaian sangat diperlukan sebagai kebutuhan pokok para manusia. Seiring dengan perkembangan kehidupan manusia, cara berpakaian digunakan sebagai simbol seseorang yang ingin bergaya dengan berpenampilan menarik. Fashion adalah suatu gaya atau style dengan kombinasi atau perpaduan dari desain pakaian (Davei et al., 2009). Menurut Badan Pusat Statistik (2017) jenis usaha disektor industri fashion adalah pembuatan pakaian jadi (konveksi) dari tekstil/kain (tenun maupun rajutan) dengan cara memotong dan menjahit sehingga siap dipakai, seperti kemeja, celana, blus, baju $t$-shirt, shirt, rok, dan pakaian olahraga, baik dari kain tenun maupun kain rajut yang dijahit. Perkembangan industri fashion memiliki ciri khas masing-masing tergantung pada adat-istiadat, kebiasaan, dan budaya di masingmasing daerah.

Industri fashion sangat bergantung pada jaman karena setiap jaman memiliki fashion yang berbeda, dengan kata lain industri fashion selalu berubahubah dan berkembang (Davei et al., 2009). Menurut King (2007) mengelola keunggulan produk yang dimiliki oleh perusahaan dapat menarik pelanggan perusahaan dan mempertahankan kualitas dalam proses pembuatan pakaian jadi untuk menarik pelanggan. Salah satu sektor yang sedang digencarkan di Indonesia adalah industri fashion. Perkembangan UKM industri fashion yang semakin meningkat, berdampak besar pada pembangunan pertumbuhan ekonomi di Indonesia (Kusumastuti, 2015). Perkembangan industri fashion yang sangat cepat dapat memberikan pengaruh terhadap kinerja UKM di Provinsi Bali (Arsha dan Suardikha, 2013).

Tabel 1.

Jumlah Usaha dan Kinerja Pemasaran Pada UKM Industri Fashion di Provinsi Bali Menurut Kabupaten/ Kota Tahun 2018.

\begin{tabular}{|c|c|c|}
\hline Kabupaten/Kota & Jumlah Usaha(Unit) & Kinerja Pemasaran (\%) \\
\hline Denpasar & 681 & 44,48 \\
\hline Klungkung & 17 & 0,41 \\
\hline Badung & 183 & 47,95 \\
\hline Buleleng & 23 & 0,57 \\
\hline Gianyar & 63 & 2,23 \\
\hline Jembrana & 23 & 0,20 \\
\hline Karangasem & 28 & 0,20 \\
\hline Tabanan & 41 & 3,38 \\
\hline Bangli & 30 & 0,8 \\
\hline
\end{tabular}

Sumber: Dinas Perindustrian dan Perdagangan Provinsi Bali, 2018

Pada Tabel 1. menunjukkan jumlah usaha dan persentase kinerja pemasaran UKM industri fashion di Provinsi Bali menurut Kabupaten/ Kota tahun 2018, dapat terlihat jumlah usaha industri fashion di Kota Denpasar memiliki jumlah 
terbanyak di Bali yaitu sebanyak 681 unit dengan persentase kinerja pemasaran 44,48 persen, sedangkan Kabupaten Badung mempunyai jumlah usaha sebesar 183 unit dengan persentase kinerja pemasaran terbanyak yaitu 47,95 persen. Berdasarkan data tersebut dapat diketahui bahwa kinerja pemasaran UKM industri fashion di Kabupaten Badung lebih tinggi daripada Kota Denpasar, walaupun Kota Denpasar memiliki jumlah UKM industri fashion yang lebih dominan dibandingkan Kabupaten Badung.

Menurut Laksmi dkk. (2018) perubahan pasar yang semakin cepat adalah faktor yang dapat menyebabkan terjadinya peningkatan atau penurunan sangat drastis dialami oleh kinerja pemasaran industri fashion beberapa tahun belakangan ini. Perkembangan fashion tidak hanya dilihat dari musim tetapi diakibatkan oleh keunikan jenis pakaian yang terjadi di dunia yang mengakibatkan berubahnya trend untuk berpakaian (Laksmi dkk., 2018). Pengusaha yang bergerak di sektor industri fashion akan berkembang sehingga dapat mengikuti perkembangan trend dan fashion yang nanti akan menjadi peluang tersendiri bagi para wirausaha.

Menurut Rudy dan Masari (2013) pasar global sangatlah bergantung pada keseriusan semua para wirausaha UKM industri fashion ini, sehingga dapat diharapkan terus berkembang untuk berkompetisi tidak hanya di pasar domestik tetapi juga pasar internasional. Gustav (2006) menyatakan bahwa masyarakat berhasil berwirausaha di lingkungan yang kondusif dengan pesatnya perkembangan UKM industri fashion di Bali dengan dukungan dari pemerintah yang merespon positif dalam kegiatan ini.

UKM di suatu negara memegang kendali yang signifikan bagi kestabilan ekonomi diakibatkan ketahanan dalam beradaptasi dari goncangan ekonomi melalui pemerataan pendapatan dan pembukaan lapangan pekerjaan (Sumiati,2015). UKM juga memiliki fleksibilitas yang tinggi jika dibandingkan dengan usaha yang berkapasitas lebih besar, sehingga UKM perlu perhatian khusus yang didukung oleh informasi akurat, agar terjadi hubungan bisnis yang terarah antara pelaku UKM dengan elemen daya saing usaha, yaitu jaringan pasar (Bank Indonesia, 2015). Kondisi produktivitas yang rendah adalah kelemahan yang membuat perkembangan dari UKM tidak dapat bertahan lama dikarenakan belum adanya kesadaran akan peluang pasar, permintaan pasar dan orientasi dari teknik pemasaran yang belum mempuni (Hartanty dan Alifah, 2013).

Meningkatnya popularitas Bali mengakibatkan tingkat wisatawan baik dari dalam maupun luar negeri menjadi konsumen yang potensial dalam pengembangan UKM (Riyaldi dan Kerti, 2016). Provinsi Bali saat ini lebih berfokus untuk meningkatkan kinerja Usaha Kecil dan Menengah (UKM). UKM memiliki potensi yang besar dalam menggerakkan kegiatan ekonomi masyarakat dan sekaligus menjadi tumpuan sumber pendapatan bagi sebagian masyarakat dalam meningkatkan kesejahteraannya. Berdasarkan Undang-Undang Nomor 20 Tahun 2008 tentang Usaha Kecil Menengah (UKM) mengatur mengenai usaha kecil memiliki kriteria nilai aset sebesar Rp. 50 juta hingga Rp. 500 juta dan omzet penjualan per tahun sebesar Rp. 300 juta hingga Rp. 2,5 miliar sedangkan untuk usaha menengah memiliki kriteria nilai aset sebesar Rp. 500 juta hingga Rp. 
10 miliar dan omzet penjualan per tahun sebesar Rp. 2,5 miliar hingga Rp. 50 miliar.

Tabel 2.

Data Perkembangan UKM di Kota Denpasar

\begin{tabular}{ccc}
\hline Tahun & Nilai Penjualan (\$) & Perkembangan (\%) \\
\hline 2014 & $535.054,93$ & 15,19 \\
2015 & $783.526,19$ & 26,47 \\
2016 & $923.840,62$ & 30,12 \\
2017 & $1.656 .056,18$ & 38,55 \\
2018 & $2.252 .203,99$ & 44,48 \\
\hline
\end{tabular}

Sumber: Dinas Perindustrian dan Perdagangan Provinsi Bali , 2018

Dari data tersebut dapat dilihat bahwa setiap tahun selalu terjadi perkembangan nilai penjualan UKM di Kota Denpasar. Berdasarkan Tabel 2. pada tahun 2014 UKM di Kota Denpasar memiliki nilai penjualan sebesar 535.054,93 dengan perkembangan 15,19 persen, pada tahun 2015 memiliki nilai penjualan sebesar 783.526,19 dengan perkembangan 26,47 persen, pada tahun 2016 memiliki nilai penjualan sebesar 923.840,62 dengan perkembangan 30,12 persen, pada tahun 2017 memiliki nilai penjualan sebesar 1.656.056,18 dengan perkembangan 38,55 persen, dan pada tahun 2018 memiliki nilai penjualan tertinggi sebesar 2.252.203,99 dengan perkembangan 44,48 persen. Dari hasil data perkembangan UKM di Kota Denpasar, maka nilai penjualan dari sebuah UKM mampu berkembang. Perkembangan tersebut seperti kreatif dan inovatif dalam menciptakan produk baru, mengetahui apa yang dibutuhkan oleh pasar (Utamaningsih, 2016). Perusahaan harus dapat mengikuti perkembangan yang ada di pasaran dan mengikuti kebutuhan yang dibutuhkan oleh konsumen.

Untuk mengetahui kinerja pemasaran yang dijalankan UKM industri fashion di Kota Denpasar telah dilakukan pra survei terhadap lima para pemilik UKM industri fashion. Dalam hasil pra survei yang telah dilakukan industri fashion di Kota Denpasar itu sendiri mengalami peningkatan terhadap kinerja pemasaran dikarenakan pemilik perusahaan sudah mampu menjangkau market share yang pelanggannya tidak hanya di kota Denpasar saja namun tersebar hingga ke seluruh wilayah Bali dengan mencari informasi tentang pangsa pasar pakaian yang diinginkan oleh pelanggan berdampak pada pembuatan pakaian yang ditawarkan memiliki sebuah inovasi produk yang setiap bulannya berubah-ubah. Pelanggan akan datang kembali membeli produknya karena setiap pembuatan desain pakaiannya sangat bervariasi mulai dari pakaian bermodel polos berkembang menjadi pakaian bergambar dan berisi tulisan yang menarik digunakan oleh pelanggan.

Menurut Bakti dan Harun (2011) sebuah keberhasilan perusahaan atau organisasi dapat diperoleh dari aktivitas proses pemasaran secara menyeluruh yang merupakan prestasi dari kinerja pemasaran. Selain itu, suatu produk yang dihasilkan perusahaan dapat mengukur sampai sejauh mana sebuah konsep yang digunakan manajemen untuk meningkatkan kinerja pemasaran (Bakti dan Harum, 2011). Faktor yang seringkali digunakan untuk mengukur dampak dari strategi yang diterapkan perusahaan merupakan kinerja pemasaran (Ferdinand dan 
Fitriani, 2015). Menurut Buzzell (2004) pemasaran terus menjadi perhatian besar dan berkembang bagi para pakar dan manajer pemasaran, penelitian menunjukkan pengaruh variabel kinerja pasar seperti pangsa pasar pada laba atas penjualan adalah pengukuran dari kinerja.

Inovasi produk dapat tercipta dan dapat ditingkatkan melalui kinerja pemasaran (Kusumo, 2006). Menurut penelitian Nazir (2017) inovasi produk berpengaruh signifikan terhadap kinerja pemasaran. Inovasi dapat menyempurnakan dan mengembangkan suatu produk dalam rangka mempertahankan kelangsungan hidup dan keuntungan perusahaan, perubahan terjadi karena adanya kinerja pemasaran (Tjiptono, 2008).

Menurut Alam (2013) orientasi pasar merupakan kebutuhan pelanggan sekarang atau masa mendatang yang berkaitan dengan pengumpulan pengawasan pasar, serta membangun komitmen pada seluruh bagian perusahaan yang akan melayani pembeli dalam informasi pasar. Kebutuhan pasar untuk mencapai tujuan organisasi, menjamin kebutuhan serta keinginan dari pelanggan, sementara secara bersamaan mempertimbangkan kepentingan seluruh pemangku kepentingan perusahaan menjadi konsep utama dari orientasi pasar (Wang et al., 2012).

Pengembangan produk dapat meningkatkan orientasi pasar yang responsif selama proses pencarian informasi mengenai inovasi produk yang diciptakan maka, tingkat responsif orientasi pasar berpengaruh secara positif dan signifikan terhadap inovasi produk (Atuahene Gima et al., 2005). Orientasi pasar berpengaruh positif dan signifikan terhadap inovasi (Narver et al., 2004). Sari (2013) menyatakan bahwa adanya pengaruh orientasi pasar terhadap kinerja pemasaran.

Menurut Agarwal et al. (2003) orientasi pasar dan inovasi ditunjukkan bahwa memiliki dampak yang signifikan terhadap kinerja meskipun banyak variasi dalam kinerja diperhitungkan oleh efek mediasi dari inovasi pada hubungan orientasi pasar terhadap kinerja. Perusahaan yang berorientasi pasar cukup kuat, akan memberi kontribusi yang positif terhadap kinerja pemasaran (Wahyono, 2002). Namun, Penelitian Han et al. (1998) menyatakan bahwa orientasi pasar berpengaruh positif tetapi tidak signifikan terhadap kinerja perusahaan.

Menurut Lin dan Chen (2007) aspek penentu terhadap kinerja perusahaan, dalam lingkungan persaingan yang semakin ketat salah satunya yaitu inovasi. Teknologi yang cepat dan variasi produk yang tinggi dalam menentukan kinerja organisasi merupakan salah satu dampak dari perubahan inovasi produk (Hartini, 2012). Hartini (2012) menyatakan bahwa inovasi produk akan meningkatkan kemampuan perusahaan menciptakan produk yang berkualitas tinggi baik itu inovasi maupun persaingan. Perusahaan yang tidak berinovasi akan ditinggalkan oleh pelanggan mereka.

Menurut Eris dan Ozmen (2012) terdapat hasil hubungan positif dari orientasi pasar dan inovasi pada kinerja perusahaan. Liao et al. (2010) menyatakan bahwa proses inovasi dapat meningkatkan kinerja bisnis sehingga inovasi berpengaruh signifikan terhadap kinerja bisnis. Handoyo (2015) menyatakan bahwa inovasi memiliki hubungan positif dan signifikan dengan 
kinerja pemasaran. Ahuja (2000) membuktikan bahwa inovasi memiliki peningkatan terhadap kinerja perusahaan, termasuk kinerja pemasaran.

Basuki dan Rahmi (2012) menunjukan bahwa orientasi pasar cukup penting dalam mendukung pelaksanaan kinerja pemasaran, sehingga orientasi pasar berpengaruh secara positif dan signifikan terhadap kinerja pemasaran. Narastika dan Yasa (2017) orientasi pasar mampu mendukung kinerja pemasaran dapat semakin meningkat atau baik selama adanya inovasi. Zhou et al. (2009) menyatakan bahwa melalui inovasi, orientasi pasar tidak secara langsung berhubungan dengan kinerja pemasaran.

Mudiantono (2005) menyatakan bahwa inovasi produk yang superior dihasilkan dari komitmen terhadap kepuasan total pelanggan yang berkelanjutan dalam organisasi berpengaruh positif dan signifikan terhadap kinerja pemasaran. Utaminingsih (2016) menyatakan bahwa orientasi pasar yang terus menerus ini akan mendorong perusahaan untuk membangun inovasi yang berpengaruh terhadap kinerja pemasarannya untuk menciptakan nilai yang superior bagi konsumen. Inovasi produk yang terus menerus disesuaikan dengan keingginan dari pelanggan dan fungsi internal serta perlu memperhatikan apa yang sudah dan akan dilakukan oleh pesaing dapat meningkatkan kinerja pemasaran (Hasanah, 2017).

Berdasarkan latar belakang yang telah dipaparkan maka rumusan masalah dalam penelitian ini adalah sebagai berikut: 1) Bagaimanakah pengaruh orientasi pasar terhadap inovasi produk pada UKM Industri Fashion di Kota Denpasar? 2) Bagaimanakah pengaruh orientasi pasar terhadap kinerja pemasaran pada UKM Industri Fashion di Kota Denpasar? 3) Bagaimanakah pengaruh inovasi produk terhadap kinerja pemasaran pada UKM Industri Fashion di Kota Denpasar? 4) Bagaimanakah pengaruh inovasi produk memediasi pengaruh orientasi pasar terhadap kinerja pemasaran pada UKM Industri Fashion di Kota Denpasar?

Berdasarkan rumusan masalah yang telah dipaparkan maka tujuan dan manfaat dari penelitian ini yaitu: 1) Untuk menjelaskan pengaruh orientasi pasar terhadap inovasi produk pada UKM Industri Fashion di Kota Denpasar. 2) Untuk menjelaskan pengaruh orientasi pasar terhadap kinerja pemasaran pada UKM Industri Fashion di Kota Denpasar. 3) Untuk menjelaskan pengaruh inovasi produk terhadap kinerja pemasaran pada UKM Industri Fashion di Kota Denpasar. 4) Untuk menjelaskan pengaruh inovasi produk memediasi pengaruh orientasi pasar terhadap kinerja pemasaran pada UKM Industri Fashion di Kota Denpasar.

Penelitian ini diharapkan dapat menambah bukti empiris tentang studi yang menjelaskan hubungan variabel orientasi pasar, inovasi produk dan kinerja pemasaran sebuah perusahaan. Penelitian ini juga diharapkan mampu memberi acuan, masukan dan menjadi referensi bagi penelitian-penelitian selanjutnya dibidang terkait.

Hasil penelitian ini diharapkan dapat menjadi informasi dan bahan pertimbangan pengambilan keputusan bagi pelaku usaha khususnya usaha UKM Industri Fashion untuk mengoptimalkan orientasi pasar dan inovasi demi tercapainya kinerja yang optimal bagi perusahaan. 
Berdasarkan hasil penelitian yang dilakukan oleh Pinho (2008) mengatakan bahwa inovasi seperti inovasi pemasaran memiliki keunggulan produk dan teknologi yang ada, maka orientasi pasar berpengaruh positif dan signifikan terhadap terciptanya inovasi. Pada jenis usaha kuliner di Kelurahan Suka Maju, perusahaan ini melakukan orientasi pasar dan menciptakan produk-produk yang inovatif karena perusahaan ini memahami apa yang dibutuhkan konsumen dan apa yang sudah pesaing mereka lakukan maka orientasi pasar yang dilakukan oleh perusahaan dapat berpengaruh secara positif dan signifikan dalam penciptaan inovasi (Dalimunthe, 2017). Lukas dan Ferrell (2000) juga menyatakan bahwa inovasi seseorang akan melakukan perubahan positif yang mengarah pada kemajuan, tetapi sebagian konsumen sulit diterima begitu saja, maka orientasi pasar dapat berpengaruh positif dan signifikan terhadap inovasi. Agarwal et al. (2003) menyatakan bahwa orientasi pasar memiliki hubungan positif dan signifikan terhadap inovasi produk. Suliyanto dan Rahab (2012) menyatakan bahwa UKM di Kabupaten Banyumas memiliki orientasi pasar yang berpengaruh positif dansignifikan terhadap inovasi produk.

Berdasarkan hasil empiris pada penelitian diatas disimpulkan bahwa yang dapat diajukan dalam penelitian ini adalah:

$\mathrm{H}_{1}$ : Orientasi pasar berpengaruh positif dan signifikan terhadap inovasi produk.

Berdasarkan hasil dari penelitian yang dilakukan oleh Merakati (2017) orientasi pasar yang dapat mempertahankan keunggulan kompetitifnya dengan cara perencanaan memuaskan kebutuhan dan keinginan pelanggan sehingga penerapan orientasi pasar akan membawa peningkatan yang siginifikan terhadap kinerja pemasaran bagi perusahaan tersebut. Sari (2013) menyatakan bahwa orientasi pasar terdapat pengaruh yang positif dan signifikan terhadap kinerja pemasaran. Kumar et al. (2011) mengemukakan berdasarkan hasil penelitiannya bahwa orientasi pasar dapat mempengaruhi kinerja dan biasanya berfokus pada retensi pelanggan dan penelitian ini menilai orientasi pasar memiliki hubungan positif dan signifikan dengan kinerja, serta penelitian yang dilakukan oleh Jabeen et al. (2013) mengenai orientasi pasar bahwa adanya hubungan yang positif dan signifikan terhadap kinerja. Hasil penelitian yang menguji hubungan antara orientasi pasar terhadap kinerja organisasi memberikan kesimpulan bahwa orientasi pasar memiliki pengaruh positif dan signifikan terhadap kinerja (Suliyanto, 2011).

Berdasarkan hasil empiris pada penelitian diatas maka disimpulkan bahwa sebuah perusahaan berorientasi pada pasar maka semakin baik kinerja pemasarannya. Jadi hipotesis yang dapat diajukan dalam penelitian ini adalah:

$\mathrm{H}_{2}$ : Orientasi pasar berpengaruh secara positif dan signifikan terhadap kinerja pemasaran.

Hasil penelitian yang diperoleh oleh Maun dan Ariyani (2002) bahwa meningkatnya inovasi produk pada pengembangan dan pengenalan produk semakin besar kinerja pemasaran yang dihasilkan maka inovasi produk berpengaruh positif dan signifikan terhadap kinerja pemasaran. Tuan et al. (2016) menyatakan bahwa inovasi sebagai proses kegiatan menyalurkan ide-ide untuk kinerja, maka inovasi dapat diukur dari hasil yang didapatkan inovasi berdampak 
positif dan signifikan pada kinerja. Hasil penelitian yang ditemukan oleh Dwiyono (2006) membuktikan bahwa tingginya inovasi produk maka mendapatkan pengaruh positif dan signifikan terhadap kinerja pemasaran yang tinggi. Farida dan Eko (2008), menyatakan bahwa sekecil apapun kemajuan negara berkembang yang menciptakan usaha kecil dari perkembangan inovasi produk dapat memberikan kontribusi secara positif dan signifikan terhadap meningkatnya kinerja pemasaran secara keseluruhan. Menurut penelitian Nazir (2017) inovasi produk juga memiliki peran yang berpengaruh secara signifikan dan signifikan terhadap kinerja pemasaran.

Berdasarkan hasil empiris pada penelitian di atas maka disimpulkan bahwa semakin berkembangnya inovasi produk yang diciptakan maka semakin meningkatnya kinerja pemsaran perusahaan tersebut. Jadi, hipotesis yang dapat diajukan dalam penelitian ini adalah:

$\mathrm{H}_{3}$ : Inovasi produk berpengaruh positif dan signifikan terhadap kinerja pemasaran.

Hasil penelitian Narastika dan Kerti Yasa (2017) mengidentifikasi bahwa orientasi pasar mendukung kinerja pemasaran yang semakin meningkat selama adanya inovasi. Pardi et al. (2014) menyatakan bahwa orientasi pasar di UKM Batik memberikan dampak yang positif dan signifikan terhadap kinerja pemasaran dimediasi oleh inovasi, bahwa kinerja pemasaran UKM Batik tergantung pada tingkat inovasi perusahaan dan juga tingkat orientasi pasar yang mempengaruhi inovasi. Prakoso (2005) menyatakan bahwa untuk mencapai keunggulan bersaing dengan hasil inovasi dapat memediasi hubungan antara orietasi pasar dengan kinerja bisnis. Selain itu penelitian yang dilakukan oleh Titahena dkk. (2012) menyatakan bahwa variabel orientasi pasar dan inovasi produk memiliki pengaruh yang signifikan terhadap kinerja pemasaran. Altuntas et al. (2013) menyatakan bahwa pada orientasi pada pasar dengan adanya inovasi yang berperan sebagai mediator untuk mendorong kinerja organisasi dalam organisasi kesehatan swasta di Turki. Berdasarkan hal tersebut maka hipotesis yang diajukan dalam penelitian ini adalah:

$\mathrm{H}_{4}$ : Inovasi produk memediasi pengaruh orientasi pasar terhadap kinerja pemasaran.

\section{METODE PENELITIAN}

Kota Denpasar dipilih sebagai lokasi penelitian karena di Denpasar merupakan pusat kota dengan tingkat jumlah usaha kecil menengah (UKM) yang lebih dominan daripada kabupaten-kabupaten lainnya sebanyak 681 unit usaha UKM industri fashion di Kota Denpasar serta sesuai dengan kriteria responden yang akan diteliti. Hal tersebut didasarkan dari data Dinas Perindustrian dan Perdagangan Provinsi Bali yang menjelaskan jumlah usaha kecil menengah (UKM) pada bagian sektor industri fashion sebanyak 681 unit dengan persentase nilai produksinya 44,69 persen. Data tersebut membuktikan bahwa masyarakat sekitar mampu memberikan dampak yang maksimal terhadap perekonomian bagi Kota Denpasar. Selain itu masyarakat ingin mengenalkan UKM industri fashion 
dengan produk lokal yang tidak kalah tandingannya terhadap fashion di Negara lain.

Populasi dalam penelitian ini adalah usaha kecil menengah (UKM) sebanyak 681 unit usaha pada sektor industri fashion di Kota Denpasar. Penelitian ini menggunakan sampel sebanyak 50 orang pemilik usaha dari 681 UKM industri fashion dari seluruh wilayah Kota Denpasar. Jumlah sampel tersebut juga tergolong layak karena masih dalam rentang antara 30 sampai dengan 500 sampel yang merupakan rentang kelayakan sampel. Teknik analisis yang digunakan dalam penelitian ini adalah analisis jalur. Analisis jalur adalah analisis regresi linier berganda yang digunakan untuk memprediksi hubungan kausalitas diantara variabel bebas yang mempengaruhi variabel terikat, melalui satu atau lebih variabel perantara yang berfungsi ganda (mediasi) secara langsung maupun tidak langsung.

Persamaan sub-struktural 1

$\mathrm{Y}_{1}=\beta_{1} \mathrm{X}+e_{1}$

Persaman sub-struktural 2

$\mathrm{Y}_{2}=\beta_{2} \mathrm{X}+\beta_{3} \mathrm{Y}_{1}+e_{2}$

Keterangan:

$$
\begin{array}{ll}
\mathrm{X} & : \text { orientasi pasar } \\
\mathrm{Y} 1 & : \text { inovasi produk } \\
\mathrm{Y} 2 & : \text { kinerja pemasaran } \\
S_{4}, \mathrm{~d} 2, \mathrm{z} ? \mathrm{l} & : \text { koefisien regresi variabel } \\
\mathrm{e}_{1}, \mathrm{e}_{2}, \mathrm{e}_{3} & : \text { eror }
\end{array}
$$

\section{HASIL DAN PEMBAHASAN}

Uji validitas bertujuan untuk memeriksa apakah kuesioner sebagai instrumen penelitian sudah tepat untuk mengukur apa yang seharusnya diukur. Suatu instrumen dikatakan valid apabila memiliki koefisien korelasi antara butir dengan skor total dalam instrumen tersebut lebih besar dari 0,30 dengan tingkat kesalahan Alpha 0,05. Tabel 3 berikut menyajikan hasil uji validitas instrumen penelitian

Tabel 3.

Rekapitulasi Hasil Uji Validitas

\begin{tabular}{ccccc}
\hline Variabel & Indikator & $\begin{array}{c}\text { Koefisien } \\
\text { Korelasi }\end{array}$ & $\begin{array}{c}\text { Sig. (2- } \\
\text { tailed) }\end{array}$ & Keterangan \\
\hline \multirow{2}{*}{ Orientasi Pasar $(\mathrm{X})$} & $\mathrm{X}_{1}$ & 0,879 & 0,000 & Valid \\
& $\mathrm{X}_{2}$ & 0,878 & 0,000 & Valid \\
& $\mathrm{X}_{3}$ & 0,819 & 0,000 & Valid \\
\multirow{3}{*}{ Inovasi Produk $\left(\mathrm{Y}_{1}\right)$} & $\mathrm{Y}_{1.1}$ & 0,663 & 0,000 & Valid \\
& $\mathrm{Y}_{1.2}$ & 0,810 & 0,000 & Valid \\
& $\mathrm{Y}_{1.3}$ & 0,725 & 0,000 & Valid \\
\multirow{3}{*}{ Kinerja pemasaran $\left(\mathrm{Y}_{2}\right)$} & $\mathrm{Y}_{1.4}$ & 0,808 & 0,000 & Valid \\
& $\mathrm{Y}_{2.1}$ & 0,718 & 0,000 & Valid \\
& $\mathrm{Y}_{2.2}$ & 0,779 & 0,000 & Valid \\
& $\mathrm{Y}_{2.3}$ & 0,749 & 0,000 & Valid \\
\hline
\end{tabular}

Sumber: Data diolah, 2018 
Hasil uji validitas pada Tabel 3. menunjukkan bahwa seluruh instrumen penelitian yang digunakan untuk mengukur variabel orientasi pasar, inovasi produk dan kinerja pemasaran memiliki nilai koefisien korelasi dengan skor total seluruh item pernyataan lebih besar dari 0,30 dengan signifikansi kurang dari 0,05 . Hal ini menunjukkan bahwa butir-butir pernyataan dalam instrument penelitian tersebut valid dan layak digunakan sebagai instrument penelitian.

Uji Reliabilitas terhadap instrumen penelitian ini menggunakan nilai Alpha Cronbach, yakni untuk mengetahui unidimensionalitas butir-butir pernyataan terhadap variabel laten yang diteliti (Orientasi Pasar, Inovasi Produk dan Kinerja pemasaran). Nilai Alpha Cronbach dinyatakan reliabel jika nilainya lebih besar atau sama dengan 0,60. Rekapitulasi hasil uji reliabilitas instrumen penelitian dapat dilihat pada Tabel 4 berikut:

Tabel 4.

Rekapitulasi Hasil Uji Reliabilitas

\begin{tabular}{clcc}
\hline No. & \multicolumn{1}{c}{ Variabel } & Cronbach's Alpha & Keterangan \\
\hline 1 & Orientasi Pasar $\left(\mathrm{X}_{1}\right)$ & 0,849 & Reliabel \\
2 & Inovasi Produk $\left(\mathrm{Y}_{1}\right)$ & 0,798 & Reliabel \\
3 & Kinerja pemasaran $\left(\mathrm{Y}_{2}\right)$ & 0,800 & Reliabel \\
\hline
\end{tabular}

Sumber: Data diolah, 2018

Hasil uji reliabilitas yang disajikan dalam Tabel 4. menunjukkan bahwa seluruh instrumen penelitian memiliki koefisien Cronbach's Alpha lebih dari 0,60 . Jadi dapat dinyatakan bahwa seluruh variabel telah memenuhi syarat reliabilitas atau kehandalan sehingga dapat digunakan untuk melakukan penelitian.

Uji normalitas bertujuan untuk mengetahui apakah residual model regresi yang dibuat berdistribusi normal atau tidak. Untuk menguji apakah data yang digunakan normal atau tidak dapat dilakukan dengan menggunakan uji Kolmogorov Sminarnov. Apabila koefisien Asymp. Sig. (2-tailed) lebih besar dari 0,05 maka data tersebut dikatakan berdistribusi normal.

Tabel 5.

Hasil Uji Normalitas Struktur 1

\begin{tabular}{lc}
\hline & Unstandardized Residual \\
\hline $\mathrm{N}$ & 50 \\
Kolmogorov-Smirnov $Z$ & 0,764 \\
Asymp.Sig.(2-tailed) & 0,604 \\
\hline
\end{tabular}

Sumber: Data diolah, 2018

Berdasarkan Tabel 5. dapat dilihat bahwa nilai Kolmogorov Sminarnov (KS) sebesar 0,764, sedangkan nilai Asymp. Sig. (2-tailed) sebesar 0,604. Hasil tersebut mengindikasikan bahwa model persamaan regresi tersebut berdistribusi normal karena nilai Asymp. Sig. (2-tailed) lebih besar dari nilai alpha 0,05.

Berdasarkan Tabel 6. dapat dilihat bahwa nilai Kolmogorov Sminarnov (KS) sebesar 0,557, sedangkan nilai Asymp. Sig. (2-tailed) sebesar 0,916. Hasil 
tersebut mengindikasikan bahwa model persamaan regresi tersebut berdistribusi normal karena nilai Asymp. Sig. (2-tailed) lebih besar dari nilai alpha 0,05.

Adanya multikolinearitas dapat dilihat dari nilai tolerance atau variance inflation factor (VIF). Jika nilai tolerance lebih dari 10\% atau VIF Kurang dari 10, maka dikatakan tidak ada multikolinearitas.

Tabel 6.

Hasil Uji Normalitas Struktur 2

\begin{tabular}{lc}
\hline & Unstandardized Residual \\
\hline $\mathrm{N}$ & 50 \\
Kolmogorov-Smirnov $Z$ & 0,557 \\
Asymp.Sig.(2-tailed) & 0,916 \\
\hline Sumber: Data diolah, 2018 &
\end{tabular}

Tabel 7.

Hasil Uji Multikoleniaritas

\begin{tabular}{lccc}
\hline \multicolumn{1}{c}{ Persamaan Struktur } & Variabel & Tolerance & VIF \\
\hline $\mathrm{Y}_{1}=\beta_{2} \mathrm{X}+\mathrm{e}_{1}$ & Orientasi Pasar (X) & 1,000 & 1,000 \\
$\mathrm{Y}_{2}=\beta_{1} \mathrm{X}+\beta_{3} \mathrm{Y}_{1}+\mathrm{e}_{2}$ & Orientasi Pasar (X) & 0,752 & 1,329 \\
& Inovasi Produk (Y1) & 0,752 & 1,329 \\
\hline
\end{tabular}

Sumber: Data diolah, 2018

Berdasarkan Tabel 7. dapat dilihat bahwa nilai tolerance dan VIF dari variabel orientasi pasar, dan inovasi produk menunjukkan nilai tolerance untuk setiap variabel lebih besar dari $10 \%$ dan nilai VIF lebih kecil dari 10 yang berarti model persamaan regresi bebas dari multikolinearitas.

Uji heteroskedastisitas bertujuan untuk mengetahui apakah dalam model regresi terjadi ketidaksamaan varians dari residual satu pengamatan ke pengamatan yang lain dan pengujian ini dilakukan dengan uji Glejser. Jika nilai signifikansinya di atas 0,05 maka tidak mengandung gejala heteroskedastisitas.

Tabel 8.

Hasil Uji Heteroskedastisitas Struktur 1

\begin{tabular}{llrrrrr}
\hline Model & \multicolumn{7}{c}{$\begin{array}{c}\text { Standardized } \\
\text { Unstandardized Coefficients } \\
\end{array}$} & \multicolumn{1}{c}{$\begin{array}{c}\text { Coefficients } \\
\text { Beta }\end{array}$} & \multicolumn{1}{c}{ T } & \multicolumn{1}{c}{ Sig. } \\
\hline 1 & (Constant) & 2.895 & 1.022 & & 2.832 & .007 \\
& Orientasi Pasar & -.118 & .084 & -.198 & -1.401 & .168 \\
\hline
\end{tabular}

Sumber: Data diolah, 2018

Pada Tabel 8. dapat dilihat bahwa nilai signifikansi dari variabel orientasi pasar sebesar 0,168. Nilai tersebut lebih besar dari 0,05 yang berarti tidak terdapat pengaruh antara variabel bebas terhadap absolute residual. Dengan demikian, model yang dibuat tidak mengandung gejala heteroskedastisitas. 
Tabel 9.

Hasil Uji Heteroskedastisitas Struktur 2

\begin{tabular}{|c|c|c|c|c|c|c|}
\hline \multirow{2}{*}{\multicolumn{2}{|c|}{ Model }} & \multicolumn{2}{|c|}{$\begin{array}{l}\text { Unstandardized } \\
\text { Coefficients }\end{array}$} & \multirow{2}{*}{$\begin{array}{c}\text { Standardized } \\
\text { Coefficients } \\
\text { Beta }\end{array}$} & \multirow[b]{2}{*}{ t } & \multirow[b]{2}{*}{ Sig. } \\
\hline & & B & Std. Error & & & \\
\hline \multirow[t]{3}{*}{1} & (Constant) & 2.249 & .862 & & 2.608 & .012 \\
\hline & Orientasi Pasar & -.108 & .061 & -.285 & -1.768 & .084 \\
\hline & Inovasi Produk & .001 & .058 & .004 & .025 & .980 \\
\hline
\end{tabular}

Sumber: Data diolah, 2018

Pada Tabel 9. dapat dilihat bahwa nilai signifikansi dari variabel orientasi pasar, dan inovasi produk, masing-masing sebesar 0,084 dan 0,980. Nilai tersebut lebih besar dari 0,05 yang berarti tidak terdapat pengaruh antara variabel bebas terhadap absolute residual. Dengan demikian, model yang dibuat tidak mengandung gejala heteroskedastisitas.

Perhitungan koefisien path dilakukan dengan analisis regresi melalui software SPSS 22.0 for Windows, diperoleh hasil yang ditunjukan pada Tabel 10 berikut.

Tabel 10.

Hasil Analisis Jalur 1

\begin{tabular}{|c|c|c|c|c|c|c|}
\hline \multirow{2}{*}{\multicolumn{2}{|c|}{ Model }} & \multicolumn{2}{|c|}{$\begin{array}{l}\text { Unstandardized } \\
\text { Coefficients }\end{array}$} & \multirow{2}{*}{$\begin{array}{c}\text { Standardized } \\
\text { Coefficients } \\
\text { Beta } \\
\end{array}$} & \multirow[b]{2}{*}{$\mathbf{t}$} & \multirow[b]{2}{*}{ Sig. } \\
\hline & & B & Std. Error & & & \\
\hline \multirow[t]{5}{*}{1} & (Constant) & 9.832 & 1.598 & & 6.154 & .000 \\
\hline & Orientasi Pasar & .522 & .131 & .498 & 3.974 & .000 \\
\hline & R Square & 0,248 & & & & \\
\hline & F Statistik & 15,793 & & & & \\
\hline & Signifikansi Uji F & 0,000 & & & & \\
\hline
\end{tabular}

Sumber: Data diolah, 2018

Berdasarkan hasil analisis jalur substruktur 1 seperti yang disajikan pada Tabel 10, maka dapat dibuat persamaan struktural sebagai berikut :

$$
\mathrm{Y} 1=0,498 \mathrm{X}
$$

Nilai koefisien regresi variabel orientasi pasar bernilai positif dengan nilai signifikansi uji t kurang dari 0,05 . Hal ini menunjukkan bahwa variabel orientasi pasar memiliki pengaruh positif yang signifikan terhadap variabel inovasi produk. Besarnya pengaruh variabel bebas terhadap variabel terikat yang ditunjukkan oleh nilai determinasi total (R Square) sebesar 0,248 mempunyai arti bahwa sebesar 24,8 persen variasi inovasi produk dipengaruhi oleh variabel orientasi pasar, sedangkan sisanya sebesar 24,8 persen dijelaskan oleh faktor lain yang tidak dimasukkan ke dalam model.

Berdasarkan hasil analisis jalur substruktur 2 seperti yang disajikan pada Tabel 11, maka dapat dibuat persamaan struktural sebagai berikut :

$$
\mathrm{Y}_{2}=0,419 \mathrm{X}+0,326 \mathrm{Y}_{1}+\mathrm{e}_{2}
$$

Nilai koefisien regresi masing-masing variabel bebas bernilai positif dengan nilai signifikansi uji t kurang dari 0,050. Hal ini menunjukkan bahwa semua variabel bebas memiliki pengaruh positif yang signifikan terhadap variabel terikat. Besarnya pengaruh variabel bebas terhadap variabel terikat yang ditunjukkan oleh 
nilai determinasi total ( $\mathrm{R}$ Square) sebesar 0,417 mempunyai arti bahwa sebesar 41,7 persen variasi Kinerja pemasaran dipengaruhi oleh variasi orientasi pasar dan inovasi produk, sedangkan sisanya sebesar 58,3 persen dijelaskan oleh faktor lain yang tidak dimasukkan ke dalam model.

Tabel 11.

Hasil Analisis Jalur 2

\begin{tabular}{|c|c|c|c|c|c|c|}
\hline \multirow{2}{*}{\multicolumn{2}{|c|}{ Model }} & \multicolumn{2}{|c|}{$\begin{array}{l}\text { Unstandardized } \\
\text { Coefficients }\end{array}$} & \multirow{2}{*}{$\begin{array}{c}\text { Standardized } \\
\text { Coefficients } \\
\text { Beta } \\
\end{array}$} & \multirow[b]{2}{*}{$\mathbf{t}$} & \multirow[b]{2}{*}{ Sig. } \\
\hline & & B & Std. Error & & & \\
\hline \multirow[t]{6}{*}{1} & (Constant) & 4.501 & 1.404 & & 3.205 & .002 \\
\hline & Orientasi Pasar & .325 & .100 & .419 & 3.261 & .002 \\
\hline & Inovasi Produk & .241 & .095 & .326 & 2.540 & .014 \\
\hline & R Square & 0,417 & & & & \\
\hline & F Statistik & 16,835 & & & & \\
\hline & Signifikansi Uji F & 0,000 & & & & \\
\hline
\end{tabular}

Sumber: Data diolah, 2018

Berdasarkan model substruktur 1 dan substruktur 2, maka dapat disusun model diagram jalur akhir. Sebelum menyusun model diagram jalur akhir, terlebih dahulu dihitung nilai standar eror sebagai berikut :

$$
\begin{aligned}
& \mathrm{Pe}_{\mathrm{i}}=\sqrt{1-\mathrm{R}_{\mathrm{i}}^{2}} \\
& \mathrm{Pe}_{1}=\sqrt{1-R_{1}{ }^{2}}=\sqrt{1-0,248}=0,867 \\
& \mathrm{Pe}_{2}=\sqrt{1-R_{2}^{2}} \text {. } \\
& =\sqrt{1-0,417}=0,763
\end{aligned}
$$

Berdasarkan perhitungan pengaruh error (Pei), didapatkan hasil pengaruh error $\left(\mathrm{Pe}_{1}\right)$ sebesar 0,867 dan pengaruh error $\left(\mathrm{Pe}_{2}\right)$ sebesar 0,763 . Hasil koefisien determinasi total adalah sebagai berikut :

$$
\begin{aligned}
\mathrm{R}^{2}{ }_{\mathrm{m}} & =1-\left(\mathrm{Pe}_{1}\right)^{2}\left(\mathrm{Pe}_{2}\right)^{2} \ldots \ldots \\
& =1-(0,867)^{2}(0,763)^{2} \\
& =1-(0,752)(0,582) \\
& =1-0,437=0,563
\end{aligned}
$$

Nilai determinasi total sebesar 0,563 mempunyai arti bahwa sebesar 56,3 persen persen variasi Kinerja pemasaran dipengaruhi oleh variasi orientasi pasar dan inovasi produk, sedangkan sisanya sebesar 43,7 persen djelaskan oleh faktor lain yang tidak dimasukkan ke dalam model.

Berdasarkan hasil analisis pengaruh Orientasi Pasar terhadap Inovasi Produk diperoleh nilai Signifikansi sebesar 0,000 dengan nilai koefisien beta 0,498. Nilai Signifikansi $0,000<0,05$ mengindikasikan bahwa $\mathrm{H}_{0}$ ditolak dan $\mathrm{H}_{1}$ diterima. Hasil ini mempunyai arti bahwa Orientasi Pasar berpengaruh positif dan signifikan terhadap Inovasi Produk pada industri fashion di Kota Denpasar.

Berdasarkan hasil analisis pengaruh Orientasi Pasar terhadap Kinerja pemasaran diperoleh nilai Signifikansi sebesar 0,002 dengan nilai koefisien beta 0,419. Nilai Signifikansi $0,002<0,05$ mengindikasikan bahwa $\mathrm{H}_{0}$ ditolak dan $\mathrm{H}_{2}$ diterima. Hasil ini mempunyai arti bahwa Orientasi Pasar berpengaruh positif dan signifikan terhadap Kinerja pemasaran pada industri fashion di Kota Denpasar. 
Berdasarkan hasil analisis pengaruh Inovasi Produk terhadap Kinerja pemasaran diperoleh nilai Signifikansi sebesar 0,014 dengan nilai koefisien beta 0,326. Nilai Signifikansi 0,014 $<0,05$ mengindikasikan bahwa $\mathrm{H}_{0}$ ditolak dan $\mathrm{H}_{3}$ diterima. Hasil ini mempunyai arti bahwa Inovasi Produk berpengaruh positif dan signifikan terhadap Kinerja pemasaran pada industri fashion di Kota Denpasar.

(3) Meringkas dan menyimpulkan

Hasil koefisien jalur pada hipotesis penelitian dapat digambarkan pada Gambar 1. berikut :

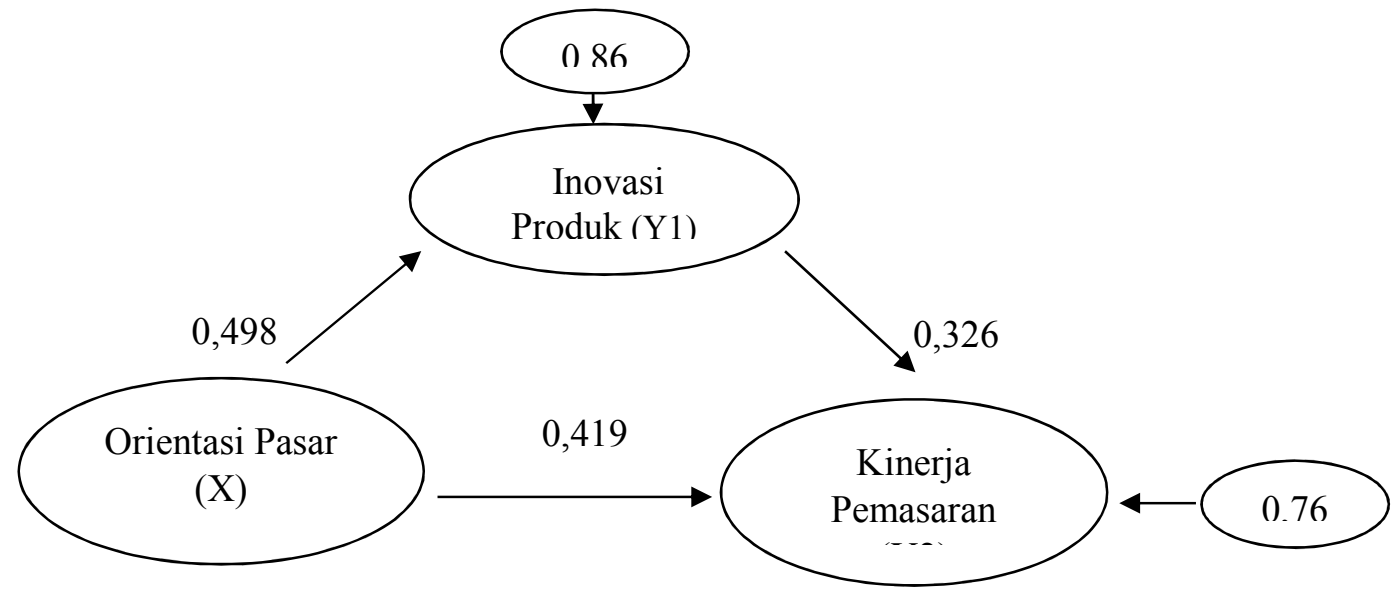

Gambar 1.

Validasi Model Diagram Jalur Akhir

Sumber: Data diolah, 2018

Berdasarkan diagram jalur pada Gambar 1, maka dapat dihitung besarnya pengaruh langsung dan pengaruh tidak langsung serta pengaruh total antar variabel. Perhitungan pengaruh antar variabel dirangkum dalam Tabel 12 sebagai berikut.:

Tabel 12.

Pengaruh Langsung dan Pengaruh Tidak Langsung serta Pengaruh Total Orientasi Pasar (X1), Inovasi Produk (Y1), dan Kinerja pemasaran (Y)

\begin{tabular}{cccc}
\hline $\begin{array}{c}\text { Pengaruh } \\
\text { Variabel }\end{array}$ & $\begin{array}{c}\text { Pengaruh } \\
\text { Langsung }\end{array}$ & $\begin{array}{c}\text { Pengaruh Tidak Langsung Melalui } \\
\text { Inovasi Produk } \\
\text { (Y1) }(\boldsymbol{\beta 1} \mathbf{~} \boldsymbol{\beta 3})\end{array}$ & Pengaruh Total \\
\hline $\mathrm{X} \rightarrow \mathrm{Y} 1$ & 0,498 & - & 0,498 \\
$\mathrm{X} \rightarrow \mathrm{Y} 2$ & 0,419 & 0,162 & 0,581 \\
$\mathrm{Y} 1 \rightarrow \mathrm{Y} 2$ & 0,326 & - & 0,326 \\
\hline \multicolumn{4}{l}{ Sumber: Data diolah, 2018}
\end{tabular}

Tabel 12. menunjukkan bahwa pengaruh langsung orientasi pasar terhadap inovasi produk adalah sebesar 0,498. Pengaruh langsung variabel orientasi pasar terhadap kinerja pemasaran sebesar 0,419. Pengaruh langsung variabel inovasi 
produk terhadap kinerja pemasaran sebesar 0,326 . Hal ini berarti bahwa variabel kinerja pemasaran lebih besar dipengaruhi oleh orientasi pasar daripada inovasi produk. Sedangkan pengaruh tidak langsung variabel orientasi pasar terhadap kinerja pemasaran melalui inovasi produk sebesar 0,162. Jadi pengaruh total variabel orientasi pasar terhadap kinerja pemasaran melalui inovasi produk adalah sebesar 0,581. Jadi dapat disimpulkan bahwa lebih besar total pengaruh orientasi pasar terhadap kinerja pemasaran yang melalui inovasi produk, daripada pengaruh langsung orientasi pasar terhadap kinerja pemasaran tanpa melalui variabel inovasi produk.

Uji sobel merupakan alat analisis untuk menguji signifikansi dari hubungan tidak langsung antara variabel independen dengan variabel dependen yang dimediasi oleh variabel mediator. Uji Sobel dirumuskan dengan persamaan berikut dan dapat dihitung dengan menggunakan aplikasi Microsoft Excel 2007. Bila nilai kalkulasi Z lebih besar dari 1,96 (dengan tingkat kepercayaan 95 persen), maka variabel mediator dinilai secara signifikan memediasi hubungan antara variabel terikat dan variabel bebas.

Untuk menguji signifikansi pengaruh tidak langsung maka nilai $\mathrm{z}$ dari koefisien ab dihitung dengan rumus sebagai berikut:

$$
\begin{aligned}
& S_{b 1 b 3}=\sqrt{(0,498)^{2}(0,095)^{2}+(0,326)^{2}(0,131)^{2}+(0,131)^{2}(0,095)^{2}} \\
& S_{b 1 b 3}=0,064938
\end{aligned}
$$

Keterangan :

$$
\begin{array}{ll}
\text { Sb1b3 } & =\text { besarnya standar error tidak langsung } \\
\text { Sb1 } & =\text { standar error koefisien } \mathrm{b} 1 \\
\text { Sb3 } & =\text { standar error koefisien } \mathrm{b} 3 \\
\mathrm{~b} 1 & =\text { jalur } \mathrm{X}_{1} \text { terhadap } \mathrm{Y}_{1} \\
\mathrm{~b} 5 & =\text { jalur } \mathrm{Y}_{1} \text { terhadap } \mathrm{Y}_{2} \\
\mathrm{~b} 1 \mathrm{~b} 5 & =\text { jalur } \mathrm{X}_{1} \text { terhadap } \mathrm{Y}_{1}\left(\mathrm{~b}_{1}\right) \text { dengan jalur } \mathrm{Y}_{1} \text { terhadap } \mathrm{Y}_{2}\left(\mathrm{~b}_{3}\right)
\end{array}
$$

Untuk menguji signifikansi pengaruh tidak langsung maka menghitung nilai $\mathrm{z}$ dari koefisien $\mathrm{ab}$ dengan rumus sebagai berikut :

$Z=\frac{b 1 b 3}{S b 1 b 3} \ldots \ldots \ldots \ldots \ldots \ldots \ldots \ldots(4)$
$Z=\frac{(0,498)(0,326)}{0,064938}$
$Z=2,5001$ dengan signifikansi 0,012

Oleh karena Z hitung sebesar 2,5001 > 1,96. Artinya Inovasi Produk $\left(\mathrm{Y}_{1}\right)$ merupakan variabel yang memediasi orientasi pasar (X) terhadap kinerja pemasaran $\left(\mathrm{Y}_{2}\right)$ pada industri fashion di Kota Denpasar atau dengan kata lain orientasi pasar berpengaruh secara tidak langsung terhadap kinerja pemasaran melalui inovasi produk.

Hasil pengujian menunjukan hubungan orientasi pasar terhadap inovasi produk memiliki koefisien beta sebesar 0,498 dengan tingkat signifikansi $0,000<$ 0,05 sehingga $\mathrm{H}_{1}$ diterima dan $\mathrm{H}_{0}$ ditolak, yang mengindikasikan bahwa orientasi 
pasar berpengaruh positif dan signifikan terhadap inovasi produk. Hal ini dapat diartikan semakin baik UKM industri fashion di Kota Denpasar melakukan orientasi pasar yang ditunjukan oleh orientasi pelanggan, orientasi pesaing, dan koordinasi antar fungsional maka inovasi produk akan meningkat.

Hasil penelitian ini mendukung penemuan Pinho (2008) mengatakan bahwa inovasi seperti inovasi pemasaran memiliki keunggulan produk dan teknologi yang ada, maka orientasi pasar berpengaruh positif dan signifikan terhadap terciptanya inovasi. Pada jenis usaha kuliner di Kelurahan Suka Maju, perusahaan ini melakukan orientasi pasar dan menciptakan produk-produk yang inovatif karena perusahaan ini memahami apa yang dibutuhkan konsumen dan apa yang sudah pesaing mereka lakukan maka orientasi pasar yang dilakukan oleh perusahaan dapat berpengaruh secara positif dan signifikan dalam penciptaan inovasi (Dalimunthe, 2017). Lukas dan Ferrell (2000) juga menyatakan bahwa inovasi seseorang akan melakukan perubahan positif yang mengarah pada kemajuan, tetapi sebagian konsumen sulit diterima begitu saja, maka orientasi pasar dapat berpengaruh positif dan signifikan terhadap inovasi. Agarwal et al. (2003) menyatakan bahwa orientasi pasar memiliki hubungan positif dan signifikan terhadap inovasi produk. Suliyanto dan Rahab (2012) menyatakan bahwa UKM di Kabupaten Banyumas memiliki orientasi pasar yang berpengaruh positif dansignifikan terhadap inovasi produk.

Pengaruh orientasi pasar terhadap kinerja pemasaran diperoleh nilai koefisien beta sebesar 0,419 dengan tingkat signifikansi $0,000<0,05$ sehingga $\mathrm{H}_{2}$ diterima dan $\mathrm{H}_{0}$ ditolak, yang mengindikasikan bahwa orientasi pasar berpengaruh positif dan signifikan terhadap kinerja pemasaran. Nilai tersebut memiliki arti bahwa UKM industri fashion di Kota Denpasar melakukan orientasi pasar yang ditujukan oleh orientasi pelanggan, orientasi pesaing, dan koordinasi antar fungsional maka kinerja pemasaran akan meningkat.

Hasil penelitian ini mendukung penemuan dari Merakati (2017) orientasi pasar yang dapat mempertahankan keunggulan kompetitifnya dengan cara perencanaan memuaskan kebutuhan dan keinginan pelanggan sehingga penerapan orientasi pasar akan membawa peningkatan yang siginifikan terhadap kinerja pemasaran bagi perusahaan tersebut. Sari (2013) menyatakan bahwa orientasi pasar terdapat pengaruh yang positif dan signifikan terhadap kinerja pemasaran. Kumar et al. (2011) mengemukakan berdasarkan hasil penelitiannya bahwa orientasi pasar dapat mempengaruhi kinerja dan biasanya berfokus pada retensi pelanggan dan penelitian ini menilai orientasi pasar memiliki hubungan positif dan signifikan dengan kinerja, serta penelitian yang dilakukan oleh Jabeen et al. (2013) mengenai orientasi pasar bahwa adanya hubungan yang positif dan signifikan terhadap kinerja. Hasil penelitian yang menguji hubungan antara orientasi pasar terhadap kinerja organisasi memberikan kesimpulan bahwa orientasi pasar memiliki pengaruh positif dan signifikan terhadap kinerja (Suliyanto, 2011)

Pengaruh inovasi produk terhadap kinerja pemasaran diperoleh nilai koefisien beta sebesar 0,326 dengan tingkat signifikansi $0,000<0,05$ sehingga $\mathrm{H}_{3}$ diterima dan $\mathrm{H}_{0}$ ditolak, yang mengindikasikan bahwa inovasi produk berpengaruh positif dan signifikan terhadap kinerja pemasaran. Hasil perhitungan 
ini memiliki makna, semakin baik UKM industri fashion di Kota Denpasar mmelakukan inovasi produk yang ditunjukan oleh menghasilkan produk dan teknologi proses pproduksi, kemampuan untuk menghasilkan produk sesuai keinginan pelanggan, mengembangkan ide-ide baru, dan mengembangkan sarana distribusi yang tepat maka kinerja pemasaran akan meningkat.

Hasil penelitian ini mendukung penemuan Maun dan Ariyani (2002) bahwa meningkatnya inovasi produk pada pengembangan dan pengenalan produk semakin besar kinerja pemasaran yang dihasilkan maka inovasi produk berpengaruh positif dan signifikan terhadap kinerja pemasaran. Tuan et al. (2016) menyatakan bahwa inovasi sebagai proses kegiatan menyalurkan ide-ide untuk kinerja, maka inovasi dapat diukur dari hasil yang didapatkan inovasi berdampak positif dan signifikan pada kinerja. Hasil penelitian yang ditemukan oleh Dwiyono (2006) membuktikan bahwa tingginya inovasi produk maka mendapatkan pengaruh positif dan signifikan terhadap kinerja pemasaran yang tinggi. Farida dan Eko (2008), menyatakan bahwa sekecil apapun kemajuan negara berkembang yang menciptakan usaha kecil dari perkembangan inovasi produk dapat memberikan kontribusi secara positif dan signifikan terhadap meningkatnya kinerja pemasaran secara keseluruhan. Menurut penelitian Nazir (2017) inovasi produk juga memiliki peran yang berpengaruh secara signifikan dan signifikan terhadap kinerja pemasaran.

Peran inovasi produk dalam memediasi pengaruh orientasi pasar terhadap kinerja pemasaran menunjukkan bahwa nilai $\mathrm{Z}$ pada uji sobel ssebesar 2,5001 atau lebih besar dari 1,96, sehingga $\mathrm{H}_{4}$ diterima dan $\mathrm{H}_{0}$ ditolak. Hal ini berarti inovasi produk mampu memediasi pengaruh orientasi pasar terhadap kinerja pemasaran pada UKM industri fashion di Kota Denpasar. Semakin baik inovasi produk maka pengaruh orientasi pasar terhadap peningkatan kinerja pemasaran semakin besar.

Hasil penelitian ini mendukung penemuan dari Narastika dan Kerti Yasa (2017) mengidentifikasi bahwa orientasi pasar mendukung kinerja pemasaran yang semakin meningkat selama adanya inovasi. Pardi et al. (2014) menyatakan bahwa orientasi pasar di UKM Batik memberikan dampak yang positif dan signifikan terhadap kinerja pemasaran dimediasi oleh inovasi, bahwa kinerja pemasaran UKM Batik tergantung pada tingkat inovasi perusahaan dan juga tingkat orientasi pasar yang mempengaruhi inovasi. Prakoso (2005) menyatakan bahwa untuk mencapai keunggulan bersaing dengan hasil inovasi dapat memediasi hubungan antara orietasi pasar dengan kinerja bisnis. Selain itu penelitian yang dilakukan oleh Titahena dkk. (2012) menyatakan bahwa variabel orientasi pasar dan inovasi produk memiliki pengaruh yang signifikan terhadap kinerja pemasaran. Altuntas et al. (2013) menyatakan bahwa pada orientasi pada pasar dengan adanya inovasi yang berperan sebagai mediator untuk mendorong kinerja organisasi dalam organisasi kesehatan swasta di Turki.

Implikasi dari hasil penelitian ini mencakup dua hal yaitu, implikasi teoretis dan implikasi praktis. Implikasi teoretis berhubungan dengan kontribusinya bagi perkembangan teori-teori mengenai variabel orientasi pasar, inovasi produk, dan kinerja pemasaran. Implikasi praktis berkaitan dengan kontribusi penelitian kepada pihak pemilik dan manajemen UKM industri fashion di Kota Denpasar sebagai bahan pertimbangan dalam merumuskan kebijakan pemasaran yang 
berhubungan dengan orientasi pasar untuk menciptakan inovasi produk yang akan berdampak pada kinerja pemasaran.

\section{SIMPULAN}

Orientasi pasar berpengaruh positif dan signifikan terhadap inovasi produk. Berarti semakin baik UKM industri fashion di Kota Denpasar melakukan orientasi pasar maka inovasi produk akan meningkat. Orientasi pasar berpengaruh positif dan signifikan terhadap kinerja pemasaran. Berarti semakin baik UKM industri fashion di Kota Denpasar melakukan orientasi pasar maka kinerja pemasaran akan meningkat.

Inovasi produk berpengaruh positif dan signifikan terhadap kinerja pemasaran. Berarti semakin baik UKM industri fashion di Kota Denpasar melakukan inovasi produk maka kinerja pemasaran akan meningkat. Inovasi produk berperan dalam memediasi secara parsial pengaruh orientasi pasar terhadap kinerja pemasaran. Berarti semakin baik UKM industri fashion di Kota Denpasar melakukan inovasi produk maka pengaruh orientasi pasar terhadap kinerja pemasaran semakin besar. Untuk meningkatkan kinerja pemasaran maka pemilik atau manajer dari UKM industri fashion di Kota Denpasar disarankan meningkatkan inovasi produk seperti menciptakan ide-ide dalam pembuatan desain pakaian yang menarik sesuai permintaan pelanggan dan mengembangkan sarana distribusi seperti memiliki lebih dari satu gerai usaha.

Pemilik atau manajer dari UKM industri fashion di Kota Denpasar disarankan meningkatkan orientasi pelanggan, orientasi pesaing, dan informasi pasar variabel dalam indikator orientasi pasar, sehingga pengaruh orientasi pasar terhadap kinerja pemasaran dapat lebih ditingkatkan sesuai dengan hasil penelitian yang telah dilakukan. Hasil penelitian menunjukan perlu adanya peningkatan pada aspek orientasi pesaing pada UKM industri fashion di Kota Denpasar agar unggul dalam bersaing sehingga orientasi pasar dapat lebih ditingkatkan. Penelitian selanjutnya disarankan untuk memperluas lokasi penelitian, melihat penelitian ini hanya dilakukan UKM industri fashion di Kota Denpasar.

\section{REFERENSI}

Agarwal, S., Erramilli, K., \& Dev, C. (2003). Market orientation and performance in service firms role of innovation. Journal of Services Marketing, 17(1), 6882.

Ahuja, G. (2000). Collaboration Networks Structural Holes and Innovation A Longitudinal Study. Administration Science Quarterly, 45(1), 425-455.

Alam, M. . (2013). Effect of Market Orientation on Small Business Perormance in Small Town In Malaysia An Emprical Study on Malaysian Small Firms. Journal of Strategic Marketing, 1(3), 144-157.

Arsha, R. M. I. M., \& Nata, K. S. (2013). Pengaruh Tingkat Upah, Tenaga Kerja Dan Modal Kerja Terhadap Produksi Industri Pakaian Jadi Tekstil (Studi Kasus Di Kota Denpasar). E-Jurnal Ekonomi Pembangunan Universitas 
Udayana, 2(8), 393-400.

Badan Pusat Statistika. (2017). Provinsi Bali Dalam Angka. Denpasar: BPS Bali.

Basuki, \& Widyanti, R. (2012). Pengaruh Strategi Keunggulan Bersaing dan Orientasi Pasar terhadap Kinerja Pemasaran Perusahaan. Jurnal Manajemen Universitas Islam Kalimantan (UNISKA) Banjarmasin, 1(2), 13-21.

Dalimunthe, M. B. (2017). Keunggulan Bersaing Melalui Orientasi Pasar dan Inovasi Produk. Jurnal Konsep Bisnis Dan Manajemen, 3(1), 18-31.

Dwiyono. (2006). Studi Mengenai Inovasi Produk dan Kinerja Pemasaran Studi Empiris pada Industri Mebel Ekspor Skala Sedang dan Besar di Jepara. Jurnal Sains Pemasaran Indonesia, 5(3), 269-286.

Eris, E. D., \& Ozmen, O. N. . (2012). The effect of market orientation, learning orientation and innovativeness. International Journal of Economic Sciences and Applied Research, 5(1), 77-108.

Farida, I., \& Eko, P. (2008). Studi mengenai inovasi produk pada usaha kecil kerajinan ukiran di Jepara. Jurnal Sains Pemasaran Indonesia, 7(2), 37-45.

Handoyo, A. S. (2015). The Effect Of Marketing Innovation, Market Orientation, And Social Capital On Competitive Advantage And Marketing Performance A Study In Msmes Of Embroidery Central Java Province. Journal of Economics Business and Accountancy Ventura, 18(3), 351-366.

Hartanty, I. T., \& R, A. (2013). Peningkatan Kinerja Pemasaran melalui Optmalisasi Keunggulan Bersaing. Jurnal Ekobis, 14(2), 72-89.

Hartini, S. (2012). Peran Inovasi: Pengembangan Kualitas Produk dan Kinerja Bisnis. Jurnal Manajemen Dan Kewirausahaan, 14(1), 82-88.

Hasanah, F. S. (2017). Pengaruh Orientasi Pasar dan Inovasi Produk Terhadap Kinerja Pemasaran Studi Pada Industri Rotan Kecil dan Menengah di Desa Trangsan Kecamatan Gatak Kabupaten Sukoharjo. Jurnal Fakultas Ekonomi Dan Bisnis Islam Institut Agama Islam Negeri Surakarta, 12(3), 178-193.

Jabeen, R., Alekam, J. M. E., Aldaoud, K. A. M., Mat, N. K. N., Zureigat, B. N. I., \& Nahi, A. K. (2013). Antecedents of FirmS Performance Empirical Evidence from Yemeni SmeS. American Journal of Economics, 3(1), 18-22.

King, K. (2007). A Case Study In The Valuation Of A Database. Journal of Database Marketing \& Customer Strategy Management, 14(2), 110-120.

Kumar, V., Jones, E., Venkatesan, R., \& Leone, R. P. (2011). Is market orientation a source of sustainable competitive advantage or simply the cost of competing. Journal of Marketing, 75(1), 16-30.

Kusumastuti, R. (2015). Developing Innovation Capability of SME Through Contextual Ambidexterity. International Journal of Administrative Science \& Organization, 22(1), 51-59. 
Laksmi, W. K., Dewi, M. H. U., \& Aswitari, L. P. (2018). Determinan Pertumbuhan Produksi Industri Pakaian Jadi di Kota Denpasar. E-Jurnal Unud, 7(1), 91-113.

Liao, S. ., Chang, W. ., \& Wu, C. . (2010). Exploring TQM Innovation relationship in continuing education: A system architecture and propositions. Total Quality Management and Business Excellence, 21(11), 1121-1139.

Lukas, B. A., \& Ferrell, O. C. (2000). The effect of market orientation on product innovation. Academy of Marketing Science Journal, 28(2), 239-247.

Maun, M., \& Ariyani. (2002). Hubungan Organizational Learning, Informasa Pasar, Inovasi dan Kinerja Pasar. Jurnal Sains Pemasaran Indonesia, 1(2), 9-16.

Merakati, I., \& Wahyono, R. (2017). Pengaruh Orientasi Pasar,Inovasi, Orientansi Kewirausahaan melalui Keunggulan Bersaing Terhadap Kinerja Pemasaran. Jurnal Edukasi Ekonomi, 6(2), 114-123.

Mudiantono, K. N. (2005). Analisis Pengaruh Faktor Lingkungan Terhadap Inovasi Produk dan Kreativitas Strategi Pemasaran Dalam Meningkatkan Kinerja Pemasaran Studi Pada Perusahaan Kerajinan Keramik di Sentra Kasongan Kabupaten Bantul Yogyakarta. Jurnal Bisnis Dan Ekonomi, 12(1), $15-23$.

Narastika, A. . R., \& Yasa, N. N. K. (2017). Peran Inovasi Produk dan Keunggulan Bersaing Memediasi Pengaruh Orientasi Pasar Terhadap Kinerja Pemasaran. E-Jurnal Manajemen Udayana, 1(2), 1-20.

Pardi, S., Suyadi, I., \& Arifin, Z. (2014). The Effect of Market Orientation and Entrepreneurial Orientation toward Learning Orientation, Innovation, Competitive Advantages and Marketing Performance. European Journal of Business and Management, 6(21), 69-80.

Pinho, J. C. (2008). TQM and Performance in Small Medium Enterprises The Mediating Effect of Customer Orientation and Innovation. International Journal of Quality and Reliability Management, 25(3), 256-275.

Prakoso, B. (2005). Pengaruh Orientasi Pasar, Inovasi, dan Orientasi Pembelajaran mempengaruhi Kinerja Untuk Mencapai Keunggulan Bersaing. Jurnal Studi Manajemen \& Organisasi, 2(1), 43-53.

Rudy, R., \& Masaru, I. (2013). The role of foreign direct investment in Indonesia's manufacturing exports. Bulletin of Indonesian Economic Studies, 49(3), 329-354.

Sari, L. F. (2013). Pengaruh Orientasi Pasar dan Kreativitas Terhadap Kinerja Pemasaran Pedagang Pakaian Jadi di Pasar Kliwon Kabupaten Kudus. Management Analysis Journal, 2(1), 110-116.

Suliyanto. (2011). Effect of Entrepreneurship Orientation and Marketing-Based 
Reward System towards Marketing Performance. International Journal of Business and Social Science, 2(6), 168-174.

Suliyanto, \& Rahab. (2012). The Role of Market Orientation and Learning Orientation in Improving Innovativeness and Performance of Small and Medium Enterprises. Asian Social Science, 8(1), 134-145.

Sumiati. (2015). Pengaruh Strategi Orientasi Wirausaha dan Orientasi Pasar Pengaruhnya terhadap Kinerja Perusahaan UMKM di Kota Surabaya. Jurnal Ilmu Ekonomi \& Manajemen, 1(1), 31-44.

Titahena, Daniel Alexander Syukur, A., \& Utomo, S. D. (2012). Analisis Pengaruh Orientasi Pasar, Inovasi dan Orientasi Kewirausahaan Terhadap Kinerja Pemasaran Dengan Intervening Keunggulan Bersaing. Jurnal Manajemen Universitas Dian Nuswantoro, 4(1), 24-33.

Tuan, N., Nguyen, N., Pham, G., \& Ngoc, N. (2016). The Effects of Innovation on Firm Performance of Supporting Industries in Hanoi Vietnam. Journal of Industrial Engineering and Management, 9(2), 413-431.

Utamaningsih, A. (2016). Pengaruh Orientasi Pasar, Inovasi dan Kreaktivitas Strategi Pemasaran Terhadap Kinerja Pemasaran Pada UKM Kerajinan Rotan di Desa Teluk Wetan Welahan Jepara. Media Ekonomi Dan Manajemen, 31(2), 77-87.

Wahyono. (2002). Orientasi Pasar dan Inovasi : Pengaruhnya Terhadap Kinerja Pemasaran Studi Kasus Pada Industri Meubel di Kabupaten Jepara. Jurnal Sains Pemasaran Indonesia, 1(1), 23-40.

Zhou, K. Z., Brown, J. R., \& Dev, C. S. (2009). Market Orientation Competitive Advantage, and Performance A Demand Based Perspective. Journal of Business Research, 6(2), 1063 - 1070. 